\title{
Effect of enamel matrix proteins on the treatment of intrabony defects. A split- mouth randomized controlled trial study
}

\author{
O efeito da proteína da matriz do esmalte no \\ tratamento de defeitos infra-ósseos. Um estudo \\ clínico controlado randomizado boca-dividida
}

Daniela Chambrone ${ }^{(a)}$

Ivan Munhoz Pasin ${ }^{(b)}$

Marina Clemente Conde ${ }^{(c)}$

Claudio Panutti(c)

Silvia Carneiro(c)

Luiz Antonio Pugliesi Alves de Lima(d)

(a) Doctorate Student in Periodontics;

(b) Master's Degree Student in Periodontics;

(c) $\mathrm{PhDs}$; (d) PhD, Associate Professor of

Periodontics - Department of Stomatology,

Division of Periodontics, School of Dentistry,

University of São Paulo.

\begin{abstract}
The objective of this split-mouth, double-blind, randomized controlled trial was to compare the clinical effect of treatment of 2- or 3-wall intrabony defects with open flap debridement (OFD) combined or not with enamel matrix proteins (EMP). Thirteen volunteers were selected with one pair of or more intrabony defects and probing pocket depth (PPD) $\geq 5 \mathrm{~mm}$. All individuals received instructions regarding oral hygiene and were submitted to scaling and root planing. Each participant received the two treatment modalities: test sites were treated with OFD and EMP, and control sites received only OFD. After 6 months, a significant reduction was observed in PPD for the EMP group (from $6.42 \pm 1.08 \mathrm{~mm}$ to $2.67 \pm 1.15 \mathrm{~mm}$ ) and for the OFD group (from $6.08 \pm 1.00 \mathrm{~mm}$ to $2.00 \pm 0.95 \mathrm{~mm})(\mathrm{p}<0.0001)$, but with no significant difference between groups $(p=0.13)$. A significant gain in relative attachment level $(R A L)$ was observed in both groups (EMP: from $13.42 \pm 1.88 \mathrm{~mm}$ to $10.75 \pm 2.26 \mathrm{~mm}, \mathrm{p}<0.001$; OFD: from $12.42 \pm 1.98 \mathrm{~mm}$ to $10.58 \pm 2.23 \mathrm{~mm}, \mathrm{p}=0.013)$, but with no significant difference between groups $(\mathrm{p}=0.85)$. Gingival recession $(\mathrm{GR})$ was higher in the EMP group (from $1.08 \pm 1.50 \mathrm{~mm}$ to $2.33 \pm 1.43 \mathrm{~mm} ; \mathrm{p}=0.0009$ ) than in the OFD group (from $0.66 \pm 1.15 \mathrm{~mm}$ to $1.16 \pm 1.33 \mathrm{~mm}$; $\mathrm{p}=0.16$ ), but this difference was not significant $(\mathrm{p}=0.06)$. In conclusion, the results showed that OFD combined with EMP was not able to improve treatment of intrabony defects compared to OFD alone.
\end{abstract}

Descriptors: Periodontics; Alveolar bone loss; Bone regeneration.

Resumo: O objetivo deste estudo clínico controlado, randomizado, duplo-cego, tipo bocadividida foi comparar o efeito clínico do tratamento de defeitos infra-ósseos de 2 ou 3 paredes com retalho de espessura total (RET) associado ou não com a proteína da matriz do esmalte (PME). Treze voluntários com 1 par ou mais de defeitos infra-ósseos foram selecionados com profundidade clínica de sondagem (PCS) $\geq 5 \mathrm{~mm}$. Todos receberam instruções de higiene bucal, raspagem e alisamento radicular. Cada participante recebeu os dois tipos de tratamento: o lado teste foi tratado com RET e PME, e o lado controle recebeu somente RET. Após 6 meses, foi observada uma redução significante na PCS para o grupo PME (de 6,42 $\pm 1,08 \mathrm{~mm}$ para 2,67 $\pm 1,15 \mathrm{~mm}$ ) e para o grupo RET (de 6,08 $\pm 1,00 \mathrm{~mm}$ para 2,00 $\pm 0,95 \mathrm{~mm})(\mathrm{p}<0,0001)$, mas não houve diferença significante entre os grupos $(\mathrm{p}=0,13)$. Um ganho significante de nível clínico de inserção relativo (NCIR) foi observado em ambos os grupos (PME: de 13,42 $\pm 1,88 \mathrm{~mm}$ para $10,75 \pm 2,26 \mathrm{~mm}, \mathrm{p}<0,001$; RET: de $12,42 \pm 1,98 \mathrm{~mm}$ para $10,58 \pm 2,23 \mathrm{~mm}, \mathrm{p}=0,013)$, mas não houve diferença significante entre os grupos $(p=0,85)$. A retração gengival $(R G)$ foi maior para o grupo PME (de 1,08 $\pm 1,50 \mathrm{~mm}$ para $2,33 \pm 1,43 \mathrm{~mm} ; \mathrm{p}=0,0009$ ) do que para o grupo RET (de $0,66 \pm 1,15 \mathrm{~mm}$ para $1,16 \pm 1,33 \mathrm{~mm} ; \mathrm{p}=0,16)$, mas essa diferença não foi significante $(p=0,06)$. Concluiu-se que o tratamento de defeitos infra-ósseos com RET associado à PME não mostrou resultados melhores que o uso de RET sozinho.

Descritores: Periodontia; Perda óssea alveolar; Regeneração óssea.
Received for publication on May 31, 2006 Sent for alterations on Oct 04, 2006 Accepted for publication on Feb 16, 2007 


\section{Introduction}

One of the major therapeutic goals of periodontal treatment is the regeneration of the principal fibers of the periodontal ligament and the insertion of these fibers into the newly formed cementum and alveolar bone. For this process to occur, undifferentiated cells within the periodontal ligament need to attach to the root surface, and then proliferate, differentiate, and produce an extracellular matrix. $^{4}$

Enamel matrix protein (EMP) is derived from the developing tooth germ of fetal pigs and has recently been introduced as a treatment option for the regenerative therapy of periodontal defects. ${ }^{6,7}$ Its use is based on the principle that EMP plays a crucial role in the development of the tooth, specifically of cementum. Histological studies in animals have shown that a new layer of cementum with inserting fibers and new alveolar bone were formed when EMP was applied to a debrided and conditioned root surface. ${ }^{5,15}$ These positive results in animals ${ }^{17}$ were later confirmed by histological findings in humans ${ }^{15}$ and by clinical improvement observed in controlled clinical trials. $3,7,8,10,13,19$

Thus, the purpose of this study was to compare the results of periodontal clinical parameters after treatment of intrabony defects with open flap debridement (OFP) combined or not with enamel matrix protein (EMP).

\section{Materials and Methods Study design}

A split-mouth, double-blind, randomized controlled clinical trial was conducted to test the efficacy of two treatment modalities for intrabony periodontal defects. The test treatment consisted of open flap access to the defect, debridement, root conditioning and application of EMP to the root surface. The same procedure was performed in the control site except for root conditioning and application of EMP. The clinical outcomes were evaluated at baseline and after 6 months. This investigation was conducted at the Department of Stomatology, Division of Periodontics, School of Dentistry, University of São Paulo (São Paulo, SP, Brazil).

\section{Calibration}

Before the study was conducted, intra-examiner calibration was performed. Clinical measurements were obtained at two different time points separated by a two-week interval. Intraclass correlation coefficients (ICC) were calculated, and the process was repeated until a good correlation was obtained $(\mathrm{ICC}=0.98)$.

\section{Sample size and subject population}

Based on a 0.8 power to detect a significant difference of $1.0 \mathrm{~mm}$ in clinical attachment level $(\alpha=0.05$, standard deviation $=1.0 \mathrm{~mm}), 13$ volunteers $(10 \mathrm{fe}$ males and 3 males, range 32-43 years) were required for the study.

The inclusion criteria were:

1. diagnosis of chronic periodontitis;

2. presence of one or more interproximal intrabony defects (2-3 walls) adjacent to vital anterior or premolar teeth;

3. absence of grade 3 mobility;

4. probing pocket depth $(\mathrm{PPD}) \geq 5 \mathrm{~mm}$;

5. plaque index (PI) score $\leq 20 \% ;^{11}$

6. keratinized tissue width of at least $2 \mathrm{~mm}$.

The exclusion criteria were:

1. presence of any systemic disease that could interfere with periodontal treatment;

2. antibiotic treatment administered during the last 6 months.

All patients were fully informed about the procedures, and their written consent was obtained. The study was approved by the Ethics Committee, School of Dentistry, University of São Paulo.

\section{Pretreatment}

Prior to surgery, each patient received oral hygiene instructions and was submitted to full-mouth, supra- and sub-gingival scaling and root planing under local anesthesia. The patients were reevaluated 6 weeks after completion of the initial therapy to determine their response to therapy and to confirm the need for periodontal surgery.

\section{Clinical measurements}

All measurements were made by a calibrated investigator (DC) who was blinded to the selected 
treatment. The main investigator (DC) was not the same that performed the surgical treatment (MC). Prior to surgery, treatment modality was assigned to each defect by a coin flip to receive either EMP following OFD or OFD alone.

Local site scores were recorded for:

1. plaque index $(\mathrm{PI}) ;^{18}$

2. gingival index $(\mathrm{GI}){ }^{9}$

3. probing pocket depth (PPD);

4. relative attachment level $(\mathrm{RAL}) ;{ }^{14}$

5. gingival recession (GR);

6. keratinized tissue band (KT);

7. dental mobility (M).

The clinical parameters PI, GI, PPD, GR and KT were measured with a manual probe (PCP-Unc, HuFriedy ${ }^{\circledR}$, Chicago, Illinois, USA). RAL was assessed with a computerized probe (Florida Probe ${ }^{\circledR}$, Florida Probe Corporation, Gainesville, Florida, USA). PPD, RAL, GR and KT measurements were made using a previously prepared stent.

The customized acrylic stent was fabricated for each surgical area and stored on the study cast to minimize distortion. The stent was grooved in an occlusoapical direction and a stop niche was prepared so that the probe would return to the same position for each successive measurement.

\section{Surgical procedures}

All sites were treated with reflection of a full thickness mucoperiosteal flap after intra-sulcular incisions. The exposed roots and osseous defects were debrided with hand instruments and the surgical wound was rinsed with saline. The OFD sites then had the flaps repositioned and sutured using 5-0 silk sutures (Tech-Lon ${ }^{\circledR}$, Techsynt/Lukens Ind. Com. Imp. e Exp. S/A, São Paulo, SP, Brazil). The EMP sites were dried with non-woven gauze, roots were conditioned with $24 \%$ ethylene diamine tetraacetic acid (EDTA) gel, pH 6.7 (Prefgel ${ }^{\circledR}$, Biora Ab, Malmö, Sweden) for $2 \mathrm{~min},{ }^{1}$ the defect was thoroughly rinsed with saline, and EMP (Emdogain ${ }^{\circledR}$, Biora Ab, Malmö, Sweden) gel was slowly applied to the deepest part of the exposed root until the defect was filled. The flaps were then replaced and sutured.

\section{Postsurgical instructions and plaque control}

The oral analgesics prescribed was paracetamol (Tylenol ${ }^{\circledR}$, Cilag Farmacêutica Ltda., São Paulo, SP, Brazil), 750 mg every 6 hours. All patients were instructed to rinse their mouth with a $0.12 \%$ solution of chlorhexidine gluconate (Periogard ${ }^{\circledR}$, Colgate-Palmolive, Divisão Kolynos do Brasil Ltda., Osasco, SP, Brazil) twice a day for 4 weeks. The patients were recalled once a week over a period of 8 weeks for professional tooth cleaning and were maintained in a supportive program in which they received professional tooth cleaning and reinforcement of self-administered oral hygiene measures at 2-month intervals up to a 6 -month reevaluation time. No attempt at probing or deep scaling was made before the end of the 6-month follow-up.

\section{Statistical analysis}

Statistical analysis was performed with the SPSS for Windows statistic software. Data were expressed as mean \pm standard deviation. The paired sample $t$ test was applied to compare groups regarding the variables PPD, RAL, GR and KT, and to evaluate changes from baseline to 6 months. For the ordinal variables PI, GI and M, the Wilcoxon signed-rank matched pair test was used for comparison between groups, and to evaluate changes from baseline to 6 months. The level of significance was set at $p<0.05$ for all tests.

\section{Results}

The 13 patients returned for the 6-month evaluation. Postoperative healing was uneventful in all cases.

At baseline, there was no significant difference between groups for any of the parameters studied. After 6 months, a significant mean reduction in PPD of 3.7 and $4.0 \mathrm{~mm}$, and a significant mean gain in relative attachment level of 2.7 and $1.8 \mathrm{~mm}$ were observed respectively for the EMP and OFD groups, with no significant difference between them (Table 1).

Gingival recession was higher in the EMP group $(1.2 \mathrm{~mm})$ than in the OFD group $(0.5 \mathrm{~mm})$. The change was significant in the EMP group only, but 
Table 1 - Mean and standard deviation values of probing pocket depth (PPD), relative attachment level (RAL), gingival recession $(G R)$, and keratinized tissue width (KT).

\begin{tabular}{|c|c|c|c|c|c|}
\hline & & $\mathrm{n}$ & Baseline & 6 months & P\# \\
\hline \multirow{3}{*}{ PPD } & EMP & 13 & $6.42 \pm 1.08$ & $2.67 \pm 1.15$ & $<0.0001^{*}$ \\
\hline & OFD & 13 & $6.08 \pm 1.00$ & $2.00 \pm 0.95$ & $<0.0001^{*}$ \\
\hline & \multicolumn{2}{|c|}{ P\# } & 0.44 & 0.13 & \\
\hline \multirow{3}{*}{ RAL } & EMP & 13 & $13.42 \pm 1.88$ & $10.75 \pm 2.26$ & $<0.001^{*}$ \\
\hline & OFD & 13 & $12.42 \pm 1.98$ & $10.58 \pm 2.23$ & $0.013^{*}$ \\
\hline & \multicolumn{2}{|c|}{ P\# } & 0.21 & 0.85 & \\
\hline \multirow{3}{*}{ GR } & EMP & 13 & $1.08 \pm 1.50$ & $2.33 \pm 1.43$ & $0.0009^{*}$ \\
\hline & OFD & 13 & $0.66 \pm 1.15$ & $1.16 \pm 1.33$ & 0.16 \\
\hline & \multicolumn{2}{|c|}{ P\# } & 0.45 & 0.06 & \\
\hline \multirow{3}{*}{ KT } & EMP & 13 & $3.58 \pm 1.24$ & $3.50 \pm 1.38$ & 0.33 \\
\hline & OFD & 13 & $4.30 \pm 1.56$ & $4.20 \pm 1.75$ & 0.34 \\
\hline & \multicolumn{2}{|c|}{ P\# } & 0.24 & 0.30 & \\
\hline
\end{tabular}

*Significant at the 0.05 level; \# paired Student $t$-test; $n=$ number of patients.

Table 2 - Mean and standard deviation values of plaque index (PI), gingival index (GI), and dental mobility (M).

\begin{tabular}{|c|c|c|c|c|c|}
\hline & & $\mathrm{n}$ & Baseline & 6 months & P\# \\
\hline \multirow{3}{*}{$\mathrm{Pl}$} & EMP & 13 & $0.83 \pm 0.38$ & $0.66 \pm 0.65$ & 0.43 \\
\hline & OFD & 13 & $0.75 \pm 0.45$ & $0.58 \pm 0.65$ & 0.55 \\
\hline & \multicolumn{2}{|c|}{ P\# } & 0.62 & 0.55 & \\
\hline \multirow{3}{*}{ Gl } & EMP & 13 & $2.00 \pm 0.12$ & $0.33 \pm 0.77$ & $<0.0001^{*}$ \\
\hline & OFD & 13 & $1.83 \pm 0.38$ & $0.50 \pm 0.90$ & $0.0012^{*}$ \\
\hline & \multicolumn{2}{|c|}{ P\# } & 0.14 & 0.62 & \\
\hline \multirow{3}{*}{ M } & EMP & 13 & $0.20 \pm 0.45$ & $0.25 \pm 0.62$ & 1.00 \\
\hline & OFD & 13 & $0.08 \pm 0.28$ & $0.08 \pm 0.28$ & 1.00 \\
\hline & \multicolumn{2}{|c|}{ P\# } & 0.28 & 0.51 & \\
\hline
\end{tabular}

*Significant at the 0.05 level; \# Wilcoxon test; $\mathrm{n}=$ number of patients.

the difference between groups was not significant. KT did not differ between groups (Table 1).

The PI scores were similar in the two groups before and after treatment. A significant decrease in GI scores was observed in the OFD and EMP groups, but there was no difference between the two groups throughout the study. Mobility scores did not differ before and after treatment (Table 2).

\section{Discussion}

The present study showed that treatment of 2- or 3 -wall intrabony defects with OFD in combination with EMP was not able to provide better outcomes than OFD alone.

The mean reduction in PPD was $3.7 \mathrm{~mm}$ for the EMP group and $4.0 \mathrm{~mm}$ for the OFD group. Previous clinical trials have shown mean PPD reductions ranging from 3.3 to $4.3 \mathrm{~mm}$ for the EMP group and from 2.2 to $3.7 \mathrm{~mm}$ for the control group at an interval of 8 to 12 months after treatment. ${ }^{3,7,10,13,19}$

In the present study, no significant differences in PPD reduction were observed between the EMP $(3.7 \mathrm{~mm})$ and OFD $(4.0 \mathrm{~mm})$ groups after 6 months. However, our results disagree with those of previ- 
ous studies that reported a significantly greater PPD reduction for the EMP group. $3,7,10,13,19$

Mean gain in relative attachment level was $2.7 \mathrm{~mm}$ for the EMP group and $1.8 \mathrm{~mm}$ for the OFD group 6 months after treatment. In previous clinical studies, the mean clinical attachment gain reported ranged from 1.7 to $4.2 \mathrm{~mm}$ for the EMP group and from 0.8 to $3.7 \mathrm{~mm}$ for the control group 8 to 12 months after treatment. . $^{3,710,13,19}$ Our result is superior to those reported by Heijl et al. ${ }^{7}$ (1997) and Okuda et al. ${ }^{10}$ (2000), who respectively observed mean clinical attachment gains of 2.1 and $1.7 \mathrm{~mm}$ for the EMP group.

However, compared to our findings, other studies have shown higher mean relative attachment level gains, of about $3.1 \mathrm{~mm}^{13,19}$ and $4.1 \mathrm{~mm} .^{3}$ In contrast to various studies, ${ }^{3,7,10,13,19}$ we observed no significant difference in mean relative attachment level after 6 months between the EMP and OFD groups.

The different PPD and RAL results obtained between our study and other different studies might be related to diverse aspects such as the place where the study was conducted, inclusion of smokers, type of intrabony defects treated, corticalization degree of the walls of the defect, type of periodontal disease treated, patient response to treatment, persistence of specific periodontal pathogens, differences in the technical ability and experience of the clinician, and capacity of clinical organization and data collection. ${ }^{19}$

One of the criteria used for selection of the present patients was a PI $\leq 20 \%$, since a low level of plaque control has a positive influence on the final treatment outcome. A control and maintenance program performed every 2 months, together with professional care and patient motivation, permitted the maintenance of a low PI which was practically unchanged throughout the experiment. A low GI was also expected, and so were better clinical outcomes since the lower the full-mouth bacterial plaque score, the better the clinical attachment level.

In the present study, improvement in the GI was observed for both groups (EMP and OFD), but with no significant difference between groups. In contrast, other investigators did not observe a significant difference in this parameter before and after treatment or between groups. ${ }^{2,3,7,10,16}$ However, Pontoriero et al..$^{13}$ (1999) and Pietruska ${ }^{12}$ (2001) demonstrated improvement in the GI from the beginning to the end of the study, but did not observe differences between groups, in agreement with the present findings. This finding is probably due to adequate bacterial plaque control performed by the patients, together with professional plaque control every 2 months, as done in the present study. It may also be attributed to a reduction of the inflammatory response as a result of the treatment applied.

An increase in GR from the beginning to the end of the experiment was observed for both the EMP and OFD groups, but this increase was only significant in the EMP group. However, no differences between groups were observed at any time during the study.

One of the factors that contribute to higher or lower gingival tissue retraction is the handling of this tissue during surgery. Previously studying the incision to be made during the flap technique allows the preservation of gingival tissue and, thus, a reduction in the amount of postoperative retraction. We opted for an intra-sulcular incision in order to preserve as much gingival tissue as possible. As long as flap manipulation during surgery is not traumatic, wound healing is favored and the risk of tissue loss is reduced. In the present study, inclusion of patients with a band of keratinized gingiva of at least $2 \mathrm{~mm}$ and care with the incision permitted the maintenance of a practically unchanged band of keratinized tissue after 6 months.

Other investigators also considered a sufficient GI to be a prerequisite for the technique, ${ }^{10,13,16,19}$ although they did not evaluate this variable in their studies.

In the present study, no significant differences in dental mobility were observed after 6 months, in agreement with the study by Okuda et al. ${ }^{10}$ (2000) who also did not report differences in dental mobility between the EMP and control groups after one year.

Within the limits of the present study, the results have shown that OFD combined with EMP was not able to improve treatment of intrabony defects compared to OFD alone. Analysis of the related literature showed that, in most studies demonstrating a 
significant difference in favor of EMP, the mean difference tends to be less than $1 \mathrm{~mm}$, a value of poor clinical significance.

\section{Conclusion}

The results showed that open flap debridment combined with enamel matrix protein was not able

\section{References}

1. Blomlöf JP, Blomlöf LB, Lindskog SF. Smear removal and collagen exposure after non-surgical root planing followed by etching with an EDTA gel preparation. J Periodontol. 1996;67(3):841-5.

2. Camargo PM, Lekovic V, Weinlaender M, Vasilic N, Barrie Kenney E, Madzarevic M. The effectiveness of enamel matrix proteins used in combination with bovine porous bone mineral in the treatment of intrabony defects in humans. J Clin Periodontol. 2001;28(11):1016-22.

3. Froum SJ, Weinberg MA, Rosenberg E, Tarnow D. A comparative study utilizing open flap debridement with and without enamel matrix derivative in the treatment of periodontal intrabony defects: A 12-month re-entry study. J Periodontol. 2001;72(1):25-34.

4. Gestrelius S, Andersson C, Lidstrom D, Hammarstrom L, Somerman M. In vitro studies on periodontal ligament cells and enamel matrix derivative. J Clin Periodontol. 1997;24(9)part II:685-92.

5. Hamamoto Y, Kawasaki N, Jarnbring F, Hammarström L. Effects and distribution of the enamel matrix derivative Emdogain ${ }^{\circledR}$ in the periodontal tissues of rat molars transplanted to the abdominal wall. Dent Traumatol. 2002;18(1):12-23.

6. Hammarström L. Enamel matrix, cementum development and regeneration. J Clin Periodontol. 1997;24(9)part II:658-68.

7. Heijl L, Heden G, Svärdström G, Östgren A. Enamel matrix derivative $\left(\mathrm{EMDOGAIN}^{\circledR}\right)$ in the treatment of intrabony periodontal defects. J Clin Periodontol. 1997;24(9)part II:705-14.

8. Lekovic V, Camargo PM, Weinlaender M, Kenney EB, Vasilic $\mathrm{N}$. Combination use of bovine porous bone mineral, enamel matrix proteins, and a bioabsorbable membrane in intrabony periodontal defects in humans. J Periodontol. 2001;72(5): 583-9.

9. Löe H. The gingival index, the plaque index and the retention index system. J Periodontol. 1967;38(6):610-6.

10. Okuda K, Momose M, Miyazaki A, Mureta M, Yokoyama $\mathrm{S}$, Yonezawa $\mathrm{Y}$ et al. Enamel matrix derivative in the treat- to improve treatment of intrabony defects compared to open flap debridement alone.

\section{Acknowledgments}

This study was supported by the State of São Paulo Research Foundation (FAPESP), São Paulo, SP, Brazil (grant \# 00/12285-0).

ment of human intrabony osseous defects. J Periodontol. 2000;71(12):1821-8.

11. O’Leary TJ, Drake RB, Naylor JE. The plaque control record. J Periodontol. 1972;43(4):38.

12. Pietruska MD. A comparative study on the Bio-Oss ${ }^{\circledR}$ and enamel matrix derivative (Emdogain ${ }^{\circledR}$ ) in the treatment of periodontal bone defects. Eur J Oral Sci. 2001;109(3): 178-81.

13. Pontoriero R, Wennström J, Lindhe J. The use of barrier membranes and enamel matrix proteins in the treatment of angular bone defects. A prospective controlled clinical study. J Clin Periodontol. 1999;26(12):833-40.

14. Reddy MS. The use of periodontal probes and radiographs in clinical trials of diagnostic tests. Ann Periodontol. 1997;2(1):113-22.

15. Sculean A, Chiantella GC, Windisch P, Donos N. Clinical and histologic evaluation of human intrabony defects treated with an enamel matrix protein derivative. Int J Periodontics Restorative Dent. 2000;20(2):375-81.

16. Sculean A, Donos N, Miliauskaite A, Arweiler N, Brecx M. Treatment of intrabony defects with enamel matrix proteins or bioabsorbable membranes. A 4-year follow-up split-mouth study. J Periodontol. 2001;72(12):1695-701.

17. Sculean A, Junker R, Donos N, Berakdar M, Brecx M, Dunker N. Immunohistochemical evaluation of matrix molecules associated with wound healing following regenerative periodontal treatment in monkeys. Clin Oral Investig. 2002;6(3): 175-82.

18. Silness J, Löe H. Periodontal disease in pregnancy II. Correlation between oral hygiene and periodontal condition. Acta Odontol Scand. 1964;22(2):121-35.

19. Tonetti MS, Lang NP, Cortellini P, Suvan JE, Adriaens P, Dubravec D et al. Enamel matrix proteins in the regenerative therapy of deep intrabony defects. J Clin Periodontol. 2002;29(4):317-25. 